ROCZNIK

TEOLOGII

KATOLICKIEJ

Tom X

Rok 2011

\title{
Łukasz Kalisz
}

Uniwersytet $w$ Białymstoku

\section{WYCHOWANIE BEZ PRZEMOCY W SYSTEMIE PREWENCYJNYM KS. JANA BOSKO}

\section{NON-VIOLENCE UPBRINGING IN THE PREVENTIVE SYSTEM OF THE REVEREND JOHN BOSCO}

In the article author describes a preventive system initiated by the Reverend John Bosco, who was an Italian priest who lived in the 19th century. His system absolutely rejected any type of corporal punishment, as it was thought to be an ineffective way of upbringing. In his pedagogical activity the Reverend John Bosco took care of desolated young boys whom he provided protection and education. Thanks to that many illiterate boys belonging to criminal groups were able to get a profession and could honestly work for themselves. The Reverend John Bosco tried to increase number of oratorios and schools and at the same time wanted to found a new friar congregation. He successfully established the Society of Salesians and from 150 years it runs many different social institutions, including the Salesianic educational centre in Różanystok.

The main goal of the research made for the article is the diagnosis of the Salesianic educational centre in Różanystok in terms of cohesion of punishment and rewards to assumptions of preventive system. The research has been made with the use of the so-called monographic method. The author proves that in that specific institution no one uses corporal punishment, in fact the only form of punishing is lack of privileges. In the most difficult cases a pupil who causes problems that harms the whole group can be punished by transferring to another institution. The system of punishments and rewards characterized in the article may be an inspiration for pedagogical educators and teachers who use the methods described in their work. 


\section{Wstęp}

Jednym z pedagogów, którzy wnieśli ogromny wkład w rozwój pedagogiki opiekuńczej, był Jan Bosko ${ }^{1}$. Po skończonym seminarium duchownym rozpoczął on praktykę wychowawczą w więzieniu turyńskim. Obserwował tam upadek moralny chłopców, którzy skazani za drobne kradzieże, przebywali w celach razem z groźnymi przestępcami. Chcąc uprzedzić negatywny wpływ środowiska, do którego wracały osoby po krótkich wyrokach, dążył do tego, aby znów nie trafili oni do więzienia. Dzięki wielkiej determinacji rozpoczął prowadzenie oratorium. Miało ono być: domem, który przygarnia; parafią, która prowadzi do spotkania z Bogiem; szkołą, która uczy i przygotowuje do dorosłego życia oraz podwórkiem, gdzie spotykają się przyjaciele i żyją radośnie ${ }^{2}$. Pomimo wielu trudności związanych ze zdobyciem środków na utrzymanie ubogiej młodzieży, liczba placówek i wychowanków bardzo szybko się powiększała. Spowodowało to konieczność wprowadzenia wspólnych zasad funkcjonowania opartych na długoletnim doświadczeniu ks. Bosko. Założone przez niego Zgromadzenie Salezjanów oparło swoją działalność na systemie prewencyjnym, który całkowicie opiera się na rozumie, religii i dobroci, dlatego nie dopuszcza żadnych kar surowych i stara się nie stosować nawet kar lżejszych ${ }^{3}$.

Celem systemu było formowanie uczciwych obywateli i dobrych chrześcijan ${ }^{4}$. Wymienione zasady stały się podstawą działalności pedagogicznej we wszystkich placówkach prowadzonych przez Towarzystwo Salezjańskie, m. in. w Salezjańskim Ośrodku Wychowawczym im. św. Jana Bosko w Różanymstoku 5 .

1 Jan Bosko (1815-1888), włoski duchowny, założyciel Towarzystwa św. Franciszka Salezego (salezjanie), współzałożycielZgromadzenia Córek Maryi Wspomożycieli(salezjanki). Opracowany przez siebie system wychowawczy realizował w zakładanych przez siebie szkołach niedzielnych, dziennych, wieczorowych, laboratoriach przyuczających do różnych zawodów, kolegiach, konwiktach, ośrodkach misyjnych i hospicjach. Jednocześnie wydawał czasopisma oraz podręczniki szkolne. W dniu śmierci księdza Bosko istniały 64 domy salezjańskie w 6 krajach, w których pracowało 768 salezjanów. Duchowość księdza Bosko i jego dokonania sprawiły, że 1 kwietnia 1934 roku ogłoszono go świętym, a jego zgromadzenie stało się drugim co do wielkości zakonem na świecie. W roku 1946 Jan Bosko został patronem prasy katolickiej. Dziś, wychowując dzieci i młodzież - zwłaszcza najuboższą - Salezjanie w liczbie około 17 tysięcy pracują w 128 krajach, a liczba salezjanek wynosi 15 tysięcy w placówkach 90 krajów. - J. Draus, R. Terlecki, Historia Wychowania wiek XIX i XX, Kraków 2005, t. 2, s. 63-64; T. Bosco, Spetniony sen - opowieść biograficzna ośw. Janie Bosko, Warszawa 2003, s. 354; L. von Matt, H. Bosco, Ksiądz Bosko, Warszawa 1994, s. 156; Z Księdzem Bosko, „Misje Salezjańskie”, wydanie specjalne, 2005, s. 3.

K. Chudzicki, Oratorium salezjańskie, „Kontakt” 2007, nr 4, s. 10.

L. Cian, System zapobiegawczy św. Jana Bosko, Warszawa 2001, s. 224.

S. Pieri, Ukierunkowanie w wychowaniu i towarzyszenie powołaniu, Warszawa 2002, s. 60.

5 Ośrodek typu resocjalizacyjnego rozpoczął funkcjonowanie 7 maja 2003 roku. Przeznaczony jest dla wychowanków z terenu całej Polski, skierowanych do ośrodka na mocy decyzji sądu. Większość wychowanków pochodzi z rodzin rozbitych i patologicznych. Przy Ośrodku pracuje bursa oraz Specjalna Szkoła Podstawowa i Gimnazjum. Placówka niesie pomoc młodzieży męskiej, pozbawionej najczęściej fundamentów miłości rodzicielskiej. Personel wychowawczy stara się tworzyć atmosferę wychowawczą, w której młodzi ludzie będą zdolni do odkrycia w sobie 
Główny problem badawczy artykułu to zdiagnozowanie, czy kary i nagrody stosowane w Ośrodku odpowiadają wymogom systemu prewencyjnego.

Artykuł oparty jest na bazie źródłowej, którą stanowią dokumenty zdeponowane w Archiwum Salezjańskiego Ośrodka Wychowawczego im. św. Jana Bosko w Różanymstoku, wzbogacone o badania wychowanków i wychowawców. Oprócz tego zastosowano obserwację uczestniczącą oraz rozmowy z wychowankami i kadrą Ośrodka. W badaniach wzięło udział 8 wychowawców Ośrodka, dyrektor i 48 wychowanków w wieku 12-18 lat, przebywających w tej placówce od dwóch tygodni do ponad trzech lat. Najwięcej podopiecznych pochodzi z dużych i średnich miast -33 osoby, z małych miast i wsi pochodzi zaledwie 15 osób.

\section{Brak kar fizycznych - wymogiem stylu wychowawczego ks. Bosko}

„Powinno się bezwzględnie unikać wszelkiego rodzaju bicia, stawiania na klęczkach w postawie bolesnej, targania za uszy i innych podobnych kar, gdyż zakazuje tego prawo cywilne, rozdrażnia to bardzo chłopców i poniża wychowawcę"6.

W sytuacjach trudnych, gdy uczeń sprawia kłopoty, a jego zachowanie nie odpowiada normom, wychowawca stawia sobie pytanie: co należy czynić? W relacjach międzyludzkich, aby człowiek przebywający z nami okazał zaufanie do naszego działania, musi czuć się bezpiecznie. Gdy wychowawca jest osobą wymierzającą surowe kary, wówczas poniża podopiecznego i ogranicza jego autentyczność w kontakcie ze sobą. Uczeń bojący się nauczyciela nie jest w stanie zaprzyjaźnić się z nim, celowo go unika i nie powierza mu swoich problemów.

Jan Bosko znał sytuację chłopców mieszających w Turynie. Wiedział, że w domu i pracy są oni zastraszani, pracodawcy używają wobec nich przemocy i nie szanują ich. Stworzył więc oratorium - miejsce pełne życzliwości, wolne od kar cielesnych. Dzięki temu zmniejszyła się agresja wśród chłopców. Ksiądz Bosko, służąc młodym, dążył do tego, aby w jego domach nie było „przepaści z powodu surowości między wychowawcami, a młodymi". Jeśli bowiem młodzi słuchają tylko z obawy lub strachu przed sankcją, to znaczy, że problem tkwi w wychowawcach. W systemie prewencyjnym strach i wychowanie nie dadzą się pogodzić?

Już za życia ksiądz Bosko dostrzegał, że salezjanie mają różne stanowiska dotyczące karania chłopców. W takich sytuacjach zachęcał ich, aby stosowali sankcje, nie tracąc ideału, jakim było wychowanie bez karania ${ }^{8}$.

wartości i sił, umożliwiających im godne życie, oparte na zrozumieniu i miłości siebie i drugiego człowieka. - http://www.rozanystok.salezjanie.pl [dostęp 15.05.20010].

6 J. Bosko, System zapobiegawczy w wychowaniu młodzieży [w:] L. Cian, System..., dz. cyt., s. 229-230.

7 J. Biesmans, Człowiek serca Jan Bosko, Warszawa 2002, s. 81.

8 Tamże, s. 84 . 
Jan Bosko zapytany, w jaki sposób ukarze jednego z wychowanków, odparł następująco: „Nie zastosuję żadnej kary. Co zrobię? Ten chłopiec jest niezdyscyplinowany, ma wprawdzie złote serce, ale jest niepozbierany i nieposłuszny. Otóż za chwilę pójdę na przerwę, wezmę go na bok i zapytam o zdrowie. Zapewne odpowie mi, że czuje się dobrze. Czy wobec tego jesteś naprawdę zadowolony z siebie? - zapytam go, patrząc mu w oczy. Na to nieoczekiwane pytanie stanie chwilę zasępiony, potem zacznie patrzeć w ziemię, zarumieni się i zamilknie. Następnie zaproszę go do spowiedzi, po której nikt już nie będzie na niego narzekał"'.

Jeśli kara jest nieunikniona, powinna być proporcjonalna do czynu. Uczeń karany zaakceptuje karę, gdy oceni swoją winę i uzna sankcję za słuszną. Po jej zastosowaniu nauczyciel powinien dać do zrozumienia, że ich przyjaźń ciągle istnieje, a zły czyn nie spowodował straty zaufania. Ksiądz Bosko zachęcał do cierpliwości w pracy z chłopcami. Dla wychowawcy znaczy to znosić, cierpieć, akceptować. Tylko dzięki cierpliwości i szybkiemu przebaczeniu wychowawca może uniknąć chęci karania. „Jeśli wychowanek dojdzie do przekonania, że wychowawca nie pragnie niczego innego, jak tylko dobra swego podopiecznego, to skuteczną karą będzie smutek widoczny w jego postawie"10.

Dzięki religijnemu charakterowi wychowania w miejsce siły fizycznej wprowadzono siłę moralną. Sumienie ukształtowane w procesie formacji duchowej sprawia, że chłopcy unikają złych czynów. Zło, które jest grzechem, na tyle obarcza sumienie, że kara fizyczna jest już zbyteczna. Często powtarzane napomnienie i salezjański sposób nauczania sprawiają, że po pewnym czasie wychowanek nie tylko sam unika okazji do czynów niemoralnych, ale też zachęca do tego rówieśników. Elementem obecności kapłanów w każdej placówce wychowawczej jest udzielanie sakramentu pojednania, po którym młody człowiek ma świadomość przebaczenia i zaczyna wszystko od nowa.

Jesienią 1860 roku do domu księdza Bosko przyjechała delegacja brytyjska. Podczas wizytacji znaleźli się oni w pomieszczeniu, gdzie duża grupa chłopców w milczeniu zajmowała się swoimi pracami. Sir James Hudson był przekonany, że placówka dysponuje sporą liczbą surowych wychowawców dbających o dyscyplinę. W sali jednak nie było żadnego z opiekunów. Pomimo tłumaczeń księdza zagraniczni goście nie mogli zrozumieć, że to nie strach, a zaufanie asystentów do wychowanków są gwarantem sukcesu ${ }^{11}$.

Każdy wychowawca powinien pracować nie tylko nad wychowaniem podopiecznych, ale też nad własnym charakterem ${ }^{12}$. Dojrzały wychowawca nie będzie popadał w złość, nawet wtedy, gdy będzie to usprawiedliwione. Powinien także

9 A. Auffray, Św. Jan Bosko, Kraków 1977, s. 173-174.

10 R. Weinschenk, Podstawy pedagogiki Księdza Bosko, Warszawa 2000, s. 131.

11 J. Biesmans, Człowiek..., dz. cyt., s. 77-78.

12 M. Jach, Rok w przedszkolu - Scenariusze w oparciu o system ks. Jana Bosko, Warszawa 1997, s. 29. 
wystrzegać się raniących uwag, pamiętając, że dyscyplina jest środkiem, a nie celem $^{13}$.

Postępowanie wychowawcze wykorzystujące „rozum” zamienia surową karę w metodę "naturalnych następstw" ${ }^{\prime 4}$. Jest to pochodna sytuacji wychowawczej sprowokowanej, aby osiągnąć przewidywaną poprawę. Naturalną konsekwencją jest kara, wymówka, pozbawienie zaufania, czy inne znane dla wychowanka następstwo. Zadaniem wychowawcy jest stałość i stanowczość w zapowiadanych i ustalonych wcześniej następstwach sytuacyjnych. Wychowanek osiągnie poprawę i nie straci szacunku do wychowawcy nawet wtedy, gdy przekroczy pewne normy. Akceptując przekroczenie ustaleń, akceptuje także naturalną konsekwencję swojego zachowania, która staje się zależna od jego wolnej woli.

W liście o karach Jan Bosko podaje i rozwija pięć zaleceń dotyczących stosowania kar w domach salezjańskich: 1) Nigdy nikogo nie karzcie, jak tylko po wyczerpaniu wszystkich możliwych środków; 2) Umiejcie na napomnienie wybrać moment odpowiedni; 3) Usuńcie wszelki ślad, który mógłby wskazywać, że działacie w gniewie; 4) Starajcie się zostawić winnemu nadzieję przebaczenia; 5) Rodzaje kar i osoby mogące je stosować ${ }^{15}$.

Jan Bosko czuł się na tyle odpowiedzialny za zachowanie swoich wychowanków, że zawsze starał się rozwiązywać spory w sposób łagodny i życzliwy: „Gdybym musiał ukarać któregoś z was, największą karę wymierzyłbym sobie” ${ }^{16}$. Ostatecznością w placówkach było usunięcie chłopca, który jest głuchy na wszelkie działania wychowawcze, a jego obecność powoduje zgorszenie. Jednak powinno się to odbyć w taki sposób, aby na tym nie ucierpiało jego dobre imię.

\section{Kary i nagrody jako sposoby oddziaływań wychowawczych w Salezjańskim Ośrodku Wychowawczym w Różanymstoku}

Do Ośrodka Wychowawczego trafiają osoby z wyrokiem sądowym, które weszły w konflikt z prawem, bądź nie realizowały obowiązku szkolnego. Ośrodek narzuca pewne normy i zasady, których należy przestrzegać. Są one zawarte w Regulaminie wewnętrznym oraz Zasadach życia w Ośrodku. W Salezjańskim Ośrodku wychowawczym kary są rozumiane jako „konsekwencje przewinień” popełnianych przez wychowanków. Słowo „konsekwencje” (zamiast „kary”) zakłada przyczynę, która powoduje pozbawienie pewnych przywilejów (ograniczenie premii kieszonkowej, wstrzymanie wyjazdów - przepustek, ograniczenie wyjazdów kulturalno - sportowych etc.) bądź rzeczywistą karę, która nie powinna poniżać podopiecznych (np. powiadomienie sądu o nagannym zachowaniu, wniosek o umieszczenie w zakładzie poprawczym). W założeniach Regulaminu Ośrodka jest mowa o tym,

\footnotetext{
13 L. von Matt, H. Bosco, Ksiądz..., dz. cyt., s. 129.

14 L. Cian, System..., dz. cyt., s. 98.

15 J.Bosko, Ostosowaniukarwdomach salezjańskich, [w:] L. Cian, System..., dz. cyt., s. 231-244.

16 E. Kłak, Jego droga... Formacja animatorów młodzieżowych, Wrocław 2001, s. 150.
} 
że należy unikać wzmocnień negatywnych, a preferować pozytywne ${ }^{17}$. Również Statut Ośrodka do obowiązków wychowawcy zalicza starania, aby w jego oddziaływaniach wychowawczych w systemie „nagród i kar” dominującą rolę odgrywały nagrody ${ }^{18}$. W praktyce przywileje i konsekwencje funkcjonują jednocześnie, jako wynik systemu punktowego. Wszystkich mieszkańców Ośrodka obejmuje ta sama punktacja: punkty dodatnie oraz ujemne. Suma punktów przekłada się następnie na nagrody w postaci przepustek, wyjazdów (na basen, wycieczek krajowych i zagranicznych), wyższego kieszonkowego, nagród rzeczowych, np. ubrań, słodyczy; są także nagrody dla całej grupy. Za ujemne punkty wychowanek najczęściej traci przywileje; w sytuacji ucieczki lub poważnych naruszeń regulaminu trafia do grupy izolacyjnej. Jest to grupa oddzielona od reszty wychowanków, chłopcy nie mają możliwości przebywania na podwórku, mają wstrzymane przepustki i inne przywileje. Aby podopieczny mógł uniknąć sytuacji, w której zostanie ukarany, powinien znać zasady i ich przestrzegać.

Z przeprowadzonych w tej placówce badań wynika, że zdecydowana większość wychowanków wie, co mogą wywołać określone przewinienia (por. wykres 1). Wszyscy wychowawcy twierdzą, że wychowankowie są świadomi konsekwencji, jakie mogą ich spotkać. Jedynie siedmiu chłopców nie wie, co ich czeka w sytuacji przewinienia.

Wykres 1. Znajomość konsekwencji negatywnych zachowań.

W sytuacji przewinienia wiem, co mnie czeka:

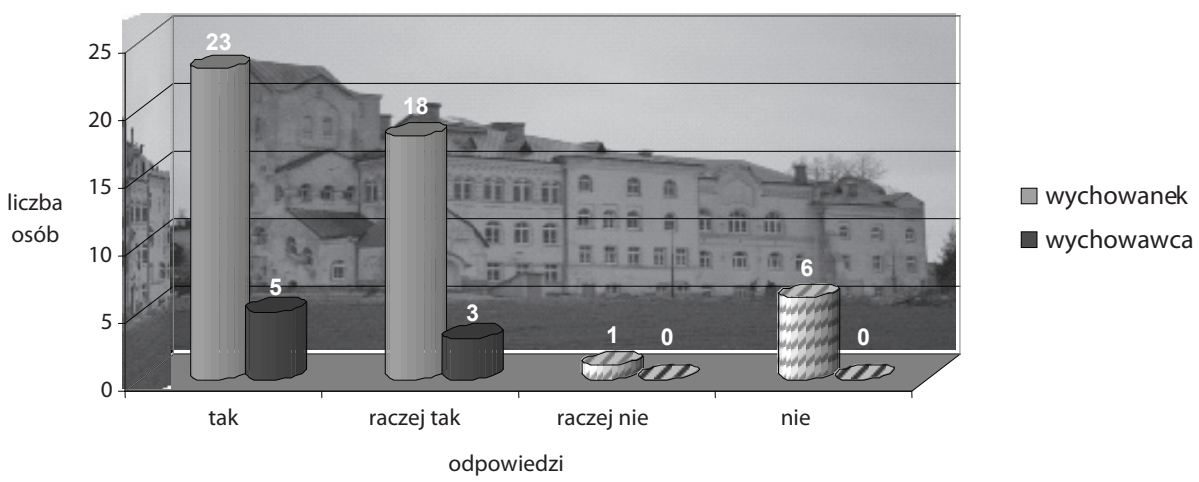

Źródło: badania własne.

17 Regulamin Wewnętrzny Salezjańskiego Ośrodka Wychowawczego w Różanymstoku, archiwum zdeponowane w sekretariacie Salezjańskiego Ośrodka Wychowawczego w Różanymstoku, s. 5-8.

18 Statut Salezjańskiego Ośrodka Wychowawczego w Różanymstoku, archiwum zdeponowane w sekretariacie Salezjańskiego Ośrodka Wychowawczego w Różanymstoku, \& 20 ust. 2 pkt 20. 
Wykres 2. Nastawienie wychowanków do kar.

Kary w Ośrodku są:

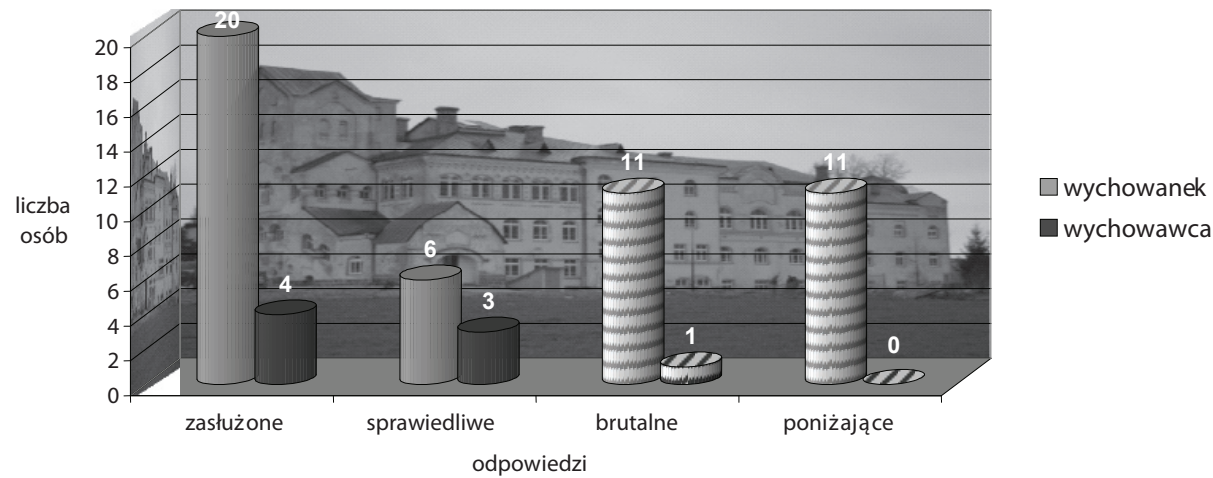

Źródło: badania własne.

Z badań można wywnioskować, że wychowankowie wiedzą, co ich czeka, gdy naruszą regulamin, lecz pomimo to nie zawsze go przestrzegają i nie chcą ponosić konsekwencji swoich czynów (por. wykres 2). Pozwala to stwierdzić, że w Ośrodku przestrzega się założeń systemu prewencyjnego dotyczących unikania karania wychowanka, jednak charakter placówki wymusza ścisłe stosowanie regulaminu i wytycznych, jakie są wpisane w istnienie placówek resocjalizacyjnych.

Badania potwierdzają skuteczność asystencji wychowawczej stosowanej w placówce. Asystent będący przyjacielem, organizatorem czasu wolnego, a także osobą zastępującą rodziców wychowanka nie tylko nagradza podopiecznego, ale też reaguje w sytuacjach nadużyć (por wykres 3). Gdy wychowanek lekceważy swoje obowiązki zostaje ukarany w postaci ujemnych punktów czy napomnienia. Świadczy to o tym, że wychowanek nie czuje się anonimowy. Wychowawcy oraz cały personel placówki, którego część mieszka w budynku Ośrodka, doskonale znają wychowanków i dbają o to, aby wszyscy w takim samym stopniu przestrzegali zasad życia w placówce. 
Wykres 3. Konsekwencje braku zaangażowania się w życie Ośrodka.

Gdy nie angażuję się w życie Ośrodka:

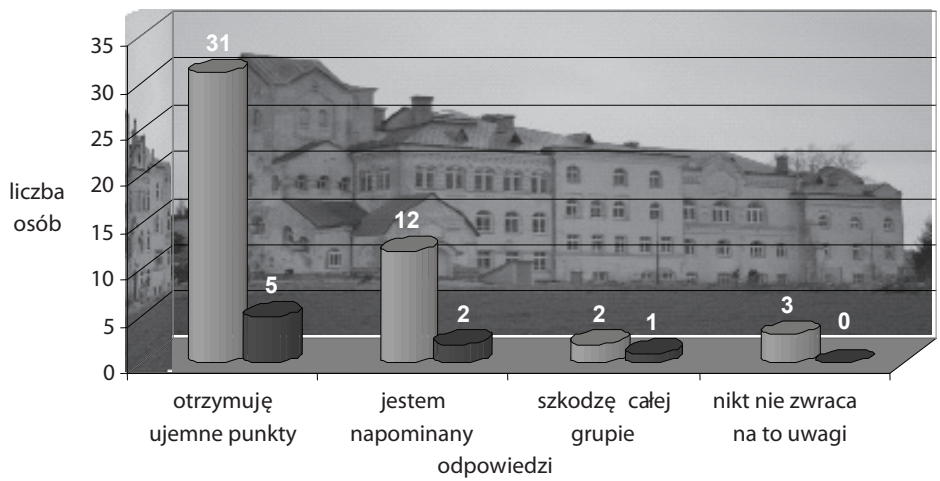

$\square$ wychowanek

wychowawca

Źródło: badania własne.

O karach w Ośrodku wychowankowie mogli się też wypowiedzieć w zdaniach niedokończonych. Większość odpowiedzi była nacechowana negatywnie (por. wykres 4). Ośmiu wychowanków odpowiedziało, że kary są zrozumiałe i zasłużone, a trzech $\mathrm{z}$ nich wyliczało konsekwencje przewinień.

Wykres 4. Skojarzenia wychowanków dotyczące kar.

Niedokończone zdanie: Kary w Ośrodku...

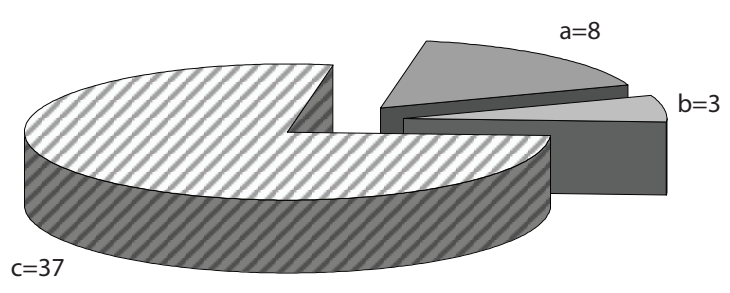

\footnotetext{
$\square$ a - są zasłużone, zrozumiałe, sprawiedliwe, konsekwentne...

$\square$ b - wyliczanie konsekwencji: izolatki, sprzątanie...

$\square$ c - są surowe, dziwne, ostre, złe...
}

Źródło: badania własne.

Świadczy to o tym, że wychowankowie nie akceptują faktu, że narzuca im się pewne normy, których powinni przestrzegać i że może ich spotkać jakaś przykra dla nich konsekwencja. Trudno jest im jednak zrozumieć, że kary mogą zostać zastąpione nagrodami. To, czy będą chcieli się zmienić, zależy od nich samych oraz od cierpliwości wychowawców, motywujących ich do zachowań pozytywnych. 


\section{Zakończenie}

W oparciu o przeprowadzone badania można stwierdzić, że kary i nagrody odpowiadają wymogom systemu prewencyjnego ks. Jana Bosko. Wychowankowie dzięki znajomości zasad znają konsekwencje swoich negatywnych zachowań, większość z nich uważa kary za zasłużone i sprawiedliwe. W Ośrodku oprócz konsekwencji są także liczne przywileje, z których często korzystają wychowankowie. Negatywne skojarzenia dotyczące kar są oczywiste i wynikają z niechęci do podporządkowania się pewnym normom, które przed pobytem w Ośrodku były im nieznane lub były powodem umieszczenia w placówce. Charakter Ośrodka Wychowawczego nie może istnieć bez sztywnego systemu kar i nagród, jednak w badanym Ośrodku jest to łączone z systemem prewencyjnym, przez co kary stają się mniej surowe, zawsze są spowodowane naruszeniem wspólnie ustalonych zasad, a w miarę możliwości poprzez nagrody wzmacnia się zachowania pozytywne. Niechęć do kar i próby łamania regulaminu są jednak zależne od wieku wychowanków i etapu ich rozwoju. Dopiero internalizacja wartości moralnych przekazywanych $\mathrm{w}$ procesie wychowania sprawia, że młody człowiek staje się osobą autonomiczną. Zadaniem Ośrodka Wychowawczego jest zatem kształtowanie właściwych postaw poprzez przykład wychowawców i cierpliwą pracę nad kształtującą się osobowością wychowanka. 